\title{
Lung Cancer Diagnostic Delay in a Havana Hospital
}

\author{
Joan F. Fernández de la Vega MD MS, Hayvin Pérez MD MS, Juan A. Samper MD MS PhD
}

\begin{abstract}
INTRODUCTION Lung cancer is one of the leading causes of death worldwide and in Cuba, where its incidence and mortality are on the rise. Diagnostic delay is a variable linked to survival and prognosis. Quantifying this delay and comparing it with data from other national and international sources may lead to planning actions to reduce its impact.
\end{abstract}

OBJECTIVE Assess diagnostic delay of lung cancer in patients at the Joaquín Albarrán Clinical-Surgical Teaching Hospital, Havana, Cuba, from 2007 to 2010 .

METHODS A retrospective descriptive study was conducted based on administrative data from patients diagnosed with lung cancer. The length of overall diagnostic delay was determined, as well delay between symptom onset and the patient's first contact with the health system, and delay at the primary and secondary levels of the national

\section{INTRODUCTION}

Lung cancer continues to be a health problem worldwide, morbidity and mortality rates increasing in recent years. Cuba is seeing a clear upward trend: mortality rates have increased from 22.3/100,000 population in 1970 to 45.3 in 2012.[1,2] There were 5097 deaths from tumors in the trachea, bronchi and lung in 2012, corresponding to a rate of 58.0/100,000 population in men and 32.5 in women.[3]

Globally, many neoplasms are diagnosed at incipient stages using simple tests, but despite extensive efforts, lung cancer diagnosis continues to be delayed. This is of particular concern, since lung carcinoma is still among the tumors with shortest patient survival rates. Although many factors are involved, one of the most important causes is diagnosis at advanced stages, which occurs in a large proportion of lung cancer patients.[4,5] Symptoms tend to appear late, making diagnosis difficult, and up to $80 \%$ of patients have inoperable tumors at diagnosis; in only $22 \%$ is the disease potentially curable.[6-8]

Havana's Joaquín Albarrán Clinical-Surgical Teaching Hospital (HDCQ) is a secondary care center offering the major clinical specialties, including internal medicine and pulmonology. This means that, even though it is not a specialized center, it has a large patient population (primarily from the municipalities of $\mathrm{La}$ Lisa, Marianao and Playa, accounting for one fifth of Havana's approximately two million people). Making rational use of available resources early detection of lung cancer and diagnostic confirmation, should be as rapid as possible, so that treatment can begin promptly, especially surgery.[9]

The time from a patient's first perception of symptoms until disease is diagnosed is known as diagnostic delay. International research on the subject has found an average diagnostic delay for lung cancer of approximately three months, while in Cuba, small-scale studies have estimated delays of three to six months, which experts consider unacceptable.[6,9-15] health system. Descriptive statistics were used to summarize the different time intervals.

RESULTS The study comprised a total of 54 patients; $74.1 \%$ were men; the largest age group was $51-60$ years. Of the total, $61.1 \%$ sought care first at the primary level. Total diagnostic delay for these patients was 67.4 days: 24.3 days due to patient delay (SD 32.8), 16.2 days due to primary care delay (SD 5.2), and 26.9 days due to secondary care delay (SD 20.1). The total delay for patients first seen at the secondary care level was 79.1 days (SD 81.8): 47.8 days due to patient delay (SD $25.6)$, and 31.3 days due to secondary level delay (SD 14.4).

CONCLUSIONS Diagnostic delay in lung cancer is high. Patients who went directly to hospital did not benefit from shorter delay in diagnosis.

KEYWORDS Lung cancer, diagnostic delay, primary level, risk perception, Cuba

Many determinants play a role in diagnostic delay. Generally, they can be divided into delays in the patients' first seeking health care and delays within the health care system. Patient delay involves several factors, mainly related to the patient's perception of symptoms, educational level, age and perceived risk, whether symptoms are typical or atypical; and health system factors, such as accessibility, can also play a role.[6] It has been suggested that lung cancer patients wait longer to see a physician than people with other types of cancer, among other reasons, because symptoms are similar to those of various respiratory diseases.[16] Health system delays are influenced by health worker expertise in symptom recognition and by availability and organization of facilities and resources.[17]

Improving prognosis and survival for lung cancer patients depends therefore on determining the components of diagnostic delay and using this information to develop local and national strategies to reduce it. The purpose of this study was to assess lung cancer diagnostic delay in HDCQ from 2007 through 2010, and to identify its various components and the times contributed by each, comparing results to those in the international literature.

\section{METHODS}

A retrospective descriptive study was conducted using administrative data from 54 patients, that is, the total number of people with a lung cancer diagnosis confirmed by cytology or biopsy in the HDCQ pathology department from 2007 through 2010. Patients either were referred from a primary care facility or went directly to the hospital. Hospital clinical records were reviewed and the data entered into Microsoft Excel databases.

Variables Data concerning sex and age at time of admission were collected, as well as the level of care of first visit (primary: family doctor-and-nurse office or community polyclinic; secondary: HDCQ—-the hospital where the study took place).

Diagnostic delay was defined as time elapsed, in days, from onset of symptoms to confirmation of diagnosisand was divided according to the following components:[11] 
- Patient delay: Time elapsed from onset of symptoms until first consultation, independent of level of care

- Primary care delay: time elapsed from patient's first primary care consultation until seen at the next level of health services

- Secondary care delay: time elapsed from patient admission and/or assessment at the secondary care level until confirmation of diagnosis

Analysis Statistical analysis was performed using InStat version 3.0 software. Absolute frequencies, percentages and SD were calculated and presented in tables.

Ethics Data from medical records were anonymized to protect patient confidentiality. The protocol was approved by the HDCQ ethics committee.

\section{RESULTS}

Of the 54 patients studied, the largest group was aged 51-60 years $(31.5 \%$; $17 / 54)$. Men outnumbered women $(74.1 \%$ vs. $25.9 \%$ ) (Table 1).

Table 1: Lung cancer patients by age and sex, HDCQ, 2007-2010 ( $n=54)$

\begin{tabular}{|l|r|r|r|r|}
\multirow{2}{*}{$\begin{array}{l}\text { Age } \\
\text { (years) }\end{array}$} & \multicolumn{5}{|c|}{ Sex } \\
\cline { 2 - 6 } & \multicolumn{2}{|c|}{ Male } & \multicolumn{2}{|c|}{ Female } \\
\hline $50(n=11)$ & $n$ & $\%$ & \multicolumn{1}{c|}{ \% } & \multicolumn{1}{c|}{} \\
\hline $51-60(n=17)$ & 8 & 20.0 & 3 & 21.4 \\
\hline $61-70(n=9)$ & 13 & 32.5 & 4 & 28.6 \\
\hline $71-80(n=10)$ & 8 & 20.0 & 1 & 7.1 \\
\hline$\geq 81(n=7)$ & 7 & 17.5 & 3 & 21.4 \\
\hline Total $(n=54)$ & 4 & 10.0 & 3 & 21.4 \\
\hline
\end{tabular}

*rounding error

HDCQ: Joaquín Albarrán Clinical-Surgical Teaching Hospital

First consultation occurred at the primary care level for $61.1 \%$ of patients (33/54). Total delay was 67.4 days for these patients: patient delay 24.3 days (SD 32.8), primary care delay 16.2 days (SD 5.2), and secondary care delay 26.9 days (SD 20.1). Among these patients, diagnostic delay at primary care level was $<7$ days in $54.5 \%$ of cases and secondary-level delay was $>16$ days in $63.6 \%$ of cases (Table 2 ).

Table 2: Components of lung cancer diagnostic delay in HDCQ patients first seen at primary care level $(n=33)$

\begin{tabular}{|c|c|c|c|c|c|c|}
\hline \multirow{3}{*}{ Delay (days) } & \multicolumn{6}{|c|}{ Component } \\
\hline & \multicolumn{2}{|c|}{ Patient } & \multicolumn{2}{|c|}{ Primary care } & \multicolumn{2}{|c|}{ Secondary care } \\
\hline & $\bar{n}$ & $\%$ & $\bar{n}$ & $\%$ & $\bar{n}$ & $\%$ \\
\hline$\leq 7$ & 14 & 42.4 & 18 & 54.5 & 0 & 0.0 \\
\hline $8-15$ & 6 & 18.2 & 4 & 12.1 & 12 & 36.4 \\
\hline $16-30$ & 7 & 21.2 & 7 & 21.2 & 16 & 48.5 \\
\hline$\geq 31$ & 6 & 18.2 & 4 & 12.1 & 5 & 15.2 \\
\hline Total & 33 & 100.0 & 33 & $99.9^{*}$ & 33 & $100.1^{*}$ \\
\hline
\end{tabular}

*rounding error

HDCQ: Joaquín Albarrán Clinical-Surgical Teaching Hospital

Patients who went directly to the secondary level had a total delay of 79.1 days (SD 81.8): patient delay 47.8 days (SD 25.6) and secondary level delay 31.3 days (SD 14.4). They experienced diagnostic delay $>16$ days in $90.5 \%$ of cases (Table 3 ). Diagnostic delay $>30$ days occurred in $74.1 \%$ of all cases, and no patients experienced total delay $<15$ days (Table 4 ).

Table 3: Components of lung cancer diagnostic delay in HDCQ patients first seen at HDCQ $(n=21)$

\begin{tabular}{|l|r|r|r|r|}
\multirow{2}{*}{ Delay (days) } & \multicolumn{5}{|c|}{ Component } \\
\cline { 2 - 5 } & \multicolumn{3}{|c|}{ Patient } & \multicolumn{2}{c|}{ Secondary care } \\
\hline$\leq 7$ & $n$ & $\%$ & \multicolumn{1}{|c|}{$n$} & $\%$ \\
\hline $8-15$ & 6 & 28.6 & 0 & 0.0 \\
\hline $16-30$ & 3 & 14.3 & 2 & 9.5 \\
\hline$\geq 31$ & 7 & 33.3 & 11 & 52.4 \\
\hline Total & 5 & 23.8 & 8 & 38.1 \\
\hline
\end{tabular}

HDCQ: Joaquín Albarrán Clinical-Surgical Teaching Hospital

Table 4: Total diagnostic delay in HDCQ lung cancer patients ( $n=54)$

\begin{tabular}{|l|r|r|}
\multirow{2}{*}{ Delay (days) } & \multicolumn{3}{|c|}{ Patients } \\
\cline { 2 - 3 } & $\mathrm{n}$ & \multicolumn{1}{|c|}{$\%$} \\
\hline $16-30$ & 14 & 25.9 \\
\hline $31-60$ & 20 & 37.0 \\
\hline $61-90$ & 12 & 22.2 \\
\hline 91 & 8 & 14.8 \\
\hline Total & 54 & $99.9^{*}$
\end{tabular}

*rounding error

HDCQ: Joaquín Albarrán Clinical-Surgical Teaching Hospital

\section{DISCUSSION}

The predominance of men in the study population is consistent with the epidemiology of lung cancer[1-3] and with other reports on diagnostic delay in Cuba.[10,11] Internationally, most patients have their first consultation at the primary care level,[18-20] and this is also the case in Cuba, where there is universal free access to health care, grounded in a national primary care network based on neighborhood family doctorand-nurse offices and community polyclinics.[20] While service accessibility is a health system characteristic, it influences the patient's ability and decision to seek attention and therefore affects the temporal lapse between symptoms and first medical contact. Cuba's extensive network of primary care facilities helps explain the fact that more than half of patients first sought care at the primary level and that those who did so delayed less than 15 days.

Our data suggest that diagnostic delay occurs at each step in the process, although patient delay had the greatest impact for those who went directly to the hospital, even longer than patient plus primary care delay for those who first sought attention at the primary level. Other research outcomes vary concerning which delay component has a greater impact on total diagnostic delay. In Cuba, Borrego found that $61.7 \%$ of diagnostic delay was due to patient-related factors,[12] while Valdés found the health system to be the greater contributor (mean delay 61.6 days).[11] Salomaa in Finland found the two components to be approximately equal.[21] The explanation for these differences could be variability in study scenarios. There might be differences in recognition of symptoms, poor assessment of symptoms, or interaction among factors.[6] Our study did not intend to delve into the reasons for delay, but only to understand its composition. 
The greater diagnostic delay at the secondary level could be due to a sporadic lack of diagnostic tools for imaging, endoscopy and pathology, or possibly to ineffective organization by $\mathrm{HDCQ}$ of available material and human resources, or lack of a suitable lung cancer protocol, such as those in other Cuban hospitals, aimed at reducing diagnostic time to seven days.[22]

The total diagnostic delay we found is considered high. Several studies agree that a total delay greater than 45 days is unacceptable; $[23,24]$ some even suggesting limits of $2-4$ weeks, though these recommendations are for the most part empirical.[25,26] Many published studies on this topic find that even the less stringent limits are not met, including Simunovic in Ontario, Canada, in 2000,[27] Myrdal in Sweden 1995-1999 (median delay 4.6 months),[28] Salomaa in Finland in 2001 (mean delay 98 days),[21] and Allgar in England 1999-2000 (mean delay 88.5 days).[15] In Cuba, Cabanes found that $59.4 \%$ of patients studied experienced a delay of $<90$ days (2003-2009)[29] and Valdés found total diagnostic delay of 73.1 days (2005-2007).[11] Borrego's 2008 study found that $47.4 \%$ of patients waited $>12$ months.[12]

The similarities between our results and those of other studies, even in more technologically advanced countries, suggest that poor organization and management of health services, not just material shortages, play an important role in diagnostic delay.
Several authors recognize this and propose setting up diagnostic assessment units, as has already been done for breast cancer. [30]

One limitation of this study is that it did not include lung cancer stage or histology at diagnosis, which could have an impact on the expression of symptoms and their perception by patient, doctor or both. Another is that we were unable to determine whether and how much patient factors or appointment availability affected delay between referral to secondary care and time seen there.

It is important to recognize which factors have a specific impact on diagnostic delay, because addressing these would have a positive effect on prognosis and survival. We recommend expanding this study to other areas of health care, looking more closely at factors explaining diagnostic delay. We also recommend public campaigns to raise awareness in people at risk of lung cancer, so they can promptly recognize early symptoms and learn about options for diagnosis and treatment.

\section{CONCLUSIONS}

Diagnostic delay in lung cancer is inadmissibly high among HDCQ patients, and those who went directly to the hospital, instead of visiting primary care facilities first, did not benefit from shorter diagnostic delay. -1 -

\section{REFERENCES}

1. Siegel R, Naishadham D, Jemal A. Cancer statistics, 2013. CA Cancer J Clin. 2013 Jan;63(1):11-30

2. Domínguez Alonso E, Seuc JA, Galán Y. Años de vida saludable perdidos por cáncer de pulmón en Cuba en años seleccionados. Rev Cubana Salud Pública [Internet]. 2011 [cited 2013 Dec 26];37(4):428-41. Available from: http://www .bvs.sld.cu/revistas/spu/vol_37_04_11/spu07411 .htm. Spanish.

3. Center for Population and Development Studies (CU). Anuario Demográfico de Cuba 2012. Havana: National Statistics Bureau (CU); 2012. Spanish.

4. Duménigo Arias $O$, De Armas Pérez B, Gil Hernández A, Gordis Aguilera MV. Nódulo pulmonar solitario: ¿Qué hacer? Rev Cubana Cir [Internet]. 2007 Apr-Jun [cited 2013 Nov 26];46(2). Available from: http://scielo.sld.cu/scie lo.php?script=sci_arttext\&pid=S0034749320070 00200009\&lng=es\&nrm=iso. Spanish.

5. Sánchez De Cos Escuín J. El cáncer de pulmón en España. Epidemiología, supervivencia y tratamiento actuales. Arch Bronconeumol. 2009 Jul;45(7):341-8. Spanish.

6. Ellis PM, Vandermeer R. Delays in the diagnosis of lung cancer. J Thorac Dis. 2011 Sep;3(3):183-8.

7. Rivera C, Mathiaux J, Haaser T, Begueret $\mathrm{H}$, Jougon J, Trouette R. [Delays in the diagnosis and treatment of lung cancer for patients treated with radiation therapy]. Bull Cancer. 2012 Dec;99(12):1117-22. French.

8. Chandra S, Mohan A, Guleria R, Singh V, Yadav $P$. Delays during the diagnostic evaluation and treatment of lung cancer. Asian Pac J Cancer Prev. 2009 Jul-Sep;10(3):453-6.

9. Almádana Pacheco V, Vázquez Martín M, Sánchez Varilla JM, Torres Gómez J, Dante García $\mathrm{H}$, Martínez Fuentes V. Demora desde el diagnóstico hasta el tratamiento quirúrgico en el cáncer de pulmón en el área hospitalaria virgen Macarena de Sevilla. An Med Interna (Madrid). 2005 Aug;22(8):361-3. Spanish.
10. Lima Guerra A, Gassiot Nuño C, Ramos Quevedo A, Rodríguez Vázquez JC, Cabanes Varona L, Morales Sánchez L, et al. Conducta diagnóstica y pronóstico en pacientes con carcinoma pulmonar de células no pequeñas en estadios quirúrgicos. Rev Cub Med. 2012 JanMar;51(1):15-24. Spanish.

11. Valdés Díaz S, García Silvera E, Pérez Cruz H. Length of diagnostic delay in patients with nonsmall-cell lung cancer. MEDICC Rev. 2010 Winter;12(1):29-32.

12. Borrego Díaz L, González Sapsin K, Borrego Pino L, Dovale Borjas B, González Sapsin K. Diagnóstico tardío del cáncer en adultos mayores. Correo Científico Médico de Holguín. 2008;12(5):1-8. Spanish.

13. Radzikowska E, Roszkowski-Śliż K, Głaz P. The impact of timeliness of care on survival in non-small cell lung cancer patients. Pneumonol Alergol Pol. 2012;80(5):422-9.

14. Sulu E, Tasolar O, Berk Takir H, Yagci Tuncer L, Karakurt Z, Yilmaz A. Delays in the diagnosis and treatment of non-small-cell lung cancer. Tumori. 2011 Nov-Dec;97(6):693-7.

15. Allgar VL, Neal RD. Delays in the diagnosis of six cancers: analysis of data from the National Survey of NHS Patients: Cancer. Br J Cancer. 2005 Jun 6;92(11):1959-70.

16. Baughan P, O'Neill B, Fletcher E. Auditing the diagnosis of cancer in primary care: the experience in Scotland. $\mathrm{Br} J$ Cancer. 2009 Dec 3:101 Suppl 2:S87-91.

17. Hueto Pérez De Heredia J, Cebollero Rivas P, Cascante Rodrigo JA, Andrade Vela I, Pascal Martínez I, Boldú Mitjans J, et al. Evaluación de la utilización de una consulta de diagnóstico rápido de cáncer de pulmón. Tiempos de demora diagnóstica y terapéutica. Arch Bronconeumol. 2012 Aug;48(8):267-73. Spanish

18. Singh $\mathrm{H}$, Hirani $\mathrm{K}$, Kadiyala $\mathrm{H}$, Rudomiotov $\mathrm{O}$, Davis T, Khan MM, et al. Characteristics and predictors of missed opportunities in lung cancer diagnosis: an electronic health record-based study. J Clin Oncol. 2010 Jul 10;28(20):3307-15.

19. Athey VL, Suckling RJ, Tod AM, Walters SJ, Rogers TK. Early diagnosis of lung cancer: evaluation of a community-based social marketing intervention. Thorax. 2012 May;67(5):412-7.

20. Álvarez Sintes R, Hernández Cabrera G, Báster Moro JC, Garcia Nuñez RD. Medicina General Integral. Havana: ECIMED; 2008. Spanish.

21. Salomaa ER, Sällinen S, Hiekkanen H, Liippo $\mathrm{K}$. Delays in the diagnosis and treatment of lung cancer. Chest. 2005 Oct;128(4):2282-8.

22. Negrín-Villavicencio JA, Soriano-García JL, Rodríguez H, Galego-Pimentel D, PérezCaballero MD, Castellanos R, editors. Manual de Prácticas Médicas del Hospital Hermanos Ameijeiras. Unidad Funcional de Tumores. 4th ed. Havana: Editorial Ciencias Médicas; 2012, pp. 886. Spanish.

23. Clemente MG, Escudero C, Alonso M, Carro $F$, Cocina B. Demora diagnóstica en el carcinoma broncogénico. Arch Bronconeumol. 2004:20(Suppl 2):1-151. Spanish.

24. Alberts WM, Bepler G, Hacelton T, Ruckdeschel JC, Williams Jr JH; American College of Chest Physicians. Lung cancer. Practice organization. Chest. 2003 Jan;123(1 Suppl):S332-7.

25. Hanna SJ, Muneer A, Khalil KH. The 2-week wait for suspected cancer: time for a rethink? Int J Clin Pract. 2005 Nov;59(11):1334-9.

26. Dodds W, Morgan M, Wolfe C, Raju KS. Implementing the 2-week wait rule for cancer referral in the UK: general practitioners' views and practices. Eur J Cancer Care (Engl). 2004 Mar;13(1):82-7.

27. Simunovic M, Gagliardi A, McCreadi D, Coates A, Levine M, DePetrillo D. A snapshot of waiting times for cancer surgery provided by surgeons affiliated with regional cancer centres in Ontario. CMAJ [Internet]. 2001 [cited 2014 Feb 26];165(4). Available from: http://www.cmaj.ca/ content/165/4/421.html 


\title{
Original Research
}

28. Myrdal G, Lambe M, Hillerdal G, Lamberg K, Agustsson T, Ståhle E. Effect of delays on prognosis in patients with non-small cell lung cancer. Thorax. 2004;59:45-9.

29. Cabanes Varona L, Rodríguez Vázquez JC, Gassiot Nuño CJ, Ramos Quevedo A, Morales Sánchez L, Lima Guerra A. Carcinoma broncógeno: Influencia de las demoras diagnósticas y terapéuticas en la supervivencia. Hospital "Hermanos Ameijeiras". 2003-2009. Neumol Cir Torax. 2011;70(2):84-93. Spanish.

30. Gagliardi A, Grunfeld E, Evans WK. Evaluation of diagnostic assessment units in oncology: a systematic review. J Clin Oncol. 2004 Mar 15;22(6):1126-35

\section{THE AUTHORS}

Joan F. Fernández de la Vega León (Corresponding author: jfabian@infomed.sld.cu), internist with a master's degree in emergencies in primary care. Instructor (at time of submission), Joaquín Albarrán Clinical-Surgical Teaching Hospital (HDCQ), Havana, Cuba.

Hayvin Pérez Cruz, pulmonologist and family physician with master's degrees in healthy aging and health informatics. Associate professor, Benéfico Jurídico Pulmonary Teaching Hospital, Havana, Cuba.
Juan A. Samper Noa, internist with a master's degree in medical and social gerontology and a doctorate in medical sciences. Full professor, National Neurosciences Center, Havana, Cuba.

Submitted: July 30, 2013

Approved for publication: November 9, 2014 Disclosures: None

\section{MEDICC Review}

Themes for Upcoming Issues

\section{5-2016 : Environment, Climate Change \& Health}

\author{
Global Health Cooperation
}

\section{Health Across Borders}

Intersectoral Initiatives for Population Health

Challenges of Healthy Aging

\section{Patlsses}

Vol. 16, No. 3-4, 2014

Dual Themes: Cancer \& Genetics

Vol. 16, No. 2, 2014

Chronic Kidney Disease Hits Agricultural Communities

Vol. 16, No. 1, 2014

Health over the Life Span

Vol. 15, No. 4, 2013

Mental Health Matters

Vol. 15, No. 3, 2013

Chronic Diseases Revisited 